\title{
Az interleukin-6-expresszió vizsgálata colorectalis adenocarcinomában szenvedő betegeken
}

\author{
Jósa Valéria dr. ${ }^{1}$ - Féderer Krisztina dr. ${ }^{2}$ - Zrubka Zsombor dr. ${ }^{3}$ \\ Reiniger Lilla dr. ${ }^{4}$. Baranyai Zsolt dr. ${ }^{5}$ \\ ${ }^{1} J a h n$ Ferenc Dél-pesti Kórház és Rendelőintézet, Fül-Orr-Gégészeti és Fej-Nyaksebészeti Osztály, Budapest \\ ${ }^{2}$ Semmelweis Egyetem, Általános Orvostudományi Kar, Szülészeti és Nőgyógyászati Klinika, Budapest \\ ${ }^{3}$ Óbudai Egyetem, HECON - Egészségügyi Közgazdaságtan Kutatóközpont, Budapest \\ ${ }^{4}$ Semmelweis Egyetem, Általános Orvostudományi Kar, I. Patológiai és Kísérleti Rákkutató Intézet, Budapest \\ ${ }^{5}$ Semmelweis Egyetem, Általános Orvostudományi Kar, I. Sebészeti Klinika, Budapest
}

Bevezetés: A gyulladásos folyamatok és a tumorok kialakulása, illetve progressziója közötti összetett kapcsolat ismert. Az interleukin-6 (IL6 ) egy pleiotrop gyulladásos citokin, melynek tumorstimuláló és -gátló tulajdonsága is van. Célkitüzés: Kutatásunk célja az IL6-expresszió vizsgálata volt colorectalis adenocarcinoma miatt reszekción átesett betegek szövettani metszetein.

Módszer: Az Uzsoki Utcai Kórházban 2004 és 2011 között reszekált 64, colorectalis tumoros beteg demográfiai, sebészeti és patológiai adatait gyújiöttük össze. A betegek szövettani metszeteit IL6-antitesttel festettük. A digitalizált metszeteket kvantitatív színelemzéssel kiértékeltük, majd az eredményeket a betegek klinikai paramétereinek függvényében elemeztük.

Eredmények: Előrehaladott stádiumú betegekben a tumorsejtek IL6-expressziója szignifikánsan magasabbnak bizonyult lineáris regresszióval. A tumorsejtek IL6-expressziója azonban nem korrelált a nemmel, az életkorral vagy a tumor differenciáltságával.

Megbeszélés: Különbségek mutatkoztak a tumorsejtek és a stromasejtek IL6-kifejeződése között.

Következtetés: Az IL6 hasznos marker és potenciális terápiás cél lehet az előrehaladottabb stádiumú colorectalis tumoros betegeknél.

Orv Hetil. 2021; 162(37): 1502-1507.

Kulcsszavak: interleukin-6, colorectalis tumor, expresszió

\section{Investigation of IL6 expression in patients with colorectal adenocarcinoma}

Introduction: It is well known that there is a complex correlation between inflammation and tumor development and tumor progression. Interleukin-6 (IL6) is a pleiotropic inflammatory cytokine with both tumor stimulating and inhibiting effect.

Objective: The goal of our study was to evaluate the IL6 expression of histological slides from patients after resection of colorectal adenocarcinoma.

Method: Demographical, surgical, and pathological findings of 64 patients with colorectal cancer operated between 2004 and 2011 in Uzsoki Teaching Hospital were evaluated. Histopathological slides were stained with IL6 antibody. The digitalized slides were assessed with quantitative color analysis, and the results were evaluated according to patients' clinical parameters.

Results: Linear regression showed significantly higher IL6 expression in the tumor cells in patients with advanced stages. However, the IL6 expression of the tumor cells did not correlate with sex, age, or tumor grade.

Discussion: There were differences between the IL6 expression in tumor cells and stromal cells.

Conclusion: IL6 may be a useful marker and potential therapeutic target in patients with advanced colorectal cancer.

Keywords: interleukin-6, colorectal tumor, expression

Jósa V, Féderer K, Zrubka Zs, Reiniger L, Baranyai Zs. [Investigation of IL6 expression in patients with colorectal adenocarcinoma]. Orv Hetil. 2021; 162(37): 1502-1507.

(Beérkezett: 2021. február 9.; elfogadva: 2021. március 9.) 


\section{Rövidítések}

ANOVA $=($ analysis of variance $)$ varianciaanalízis; $\mathrm{APC}=$ adenomatosus polyposis coli gén; BRAF $=$ (rapidly accelerated fibrosarcoma B) a rapidan gyorsuló fibrosarcomakináz-család B-tagja; CD4 = (cluster of differentiation 4$)$ differenciációs klaszter-4; $\mathrm{CpG}=$ (cytosine-phosphate-guanine) citozin-foszfát-guanin; $\mathrm{CTNNBl}=($ catenin beta 1$)$ katenin- $\beta 1$-kódoló gén; DNMT1 = (DNA methyltransferase) DNS-metil-transzferáz enzim; DNS = dezoxiribonukleinsav; ERBB2 = Erb-B2 receptor tirozin-protein kináz-2; ETT TUKEB = Egészségügyi Tudományos Tanács, Tudományos és Kutatásetikai Bizottság; IL6 = interleukin-6; MDSC = (myeloid-derived suppressor cells) myeloid eredetû́ szuppresszor sejtek; miRNS = mikro-ribonukleinsav; $\mathrm{mRNS}=$ ( messenger RNS $)$ hírvivő ribonukleinsav; STAT3 = (signal transducer and activator of transcription 3 ) jelátvivő és transzkripciós aktivátor-3; STKIl = szerin/treonin kináz-11; TAM = tumorasszociált macrophagok; TNM = tumor, nodus, metastasis; TP53 = tumorprotein -53

A vastag- és végbélrák világszerte élen áll a daganatos megbetegedések statisztikáit illetően. Európában a lakosság kor szerinti megoszlásával korrigált, 100000 lakosra jutó esetek száma alapján a betegség incidenciája férfiaknál 12,3\%, nőknél pedig 13,1\% [1]. A Nemzeti Rákregiszter adatai alapján 2015-ben hazánkban közel 5800 férfinél és mintegy 4700 nőnél diagnosztizálták ezt a daganattípust. A daganatos megbetegedések növekvő gyakorisága és az általuk okozott fokozódó népegészségügyi probléma miatt fontos az etiológia minél részletesebb megismerése, a kialakulás mechanizmusának akár molekuláris szinten történő feltérképezése. A patomechanizmus hátterében álló különféle jelátvivő folyamatok ismeretével olyan markerek azonosítására nyílhat lehetőség, melyek segítségével sikeresebb lehet a kezelés. Számos tanulmány kimutatta, hogy a vastagbéltumorok a krónikus gyulladás helyén alakulnak ki [2]. Gyulladásos sejtek, kemo- és citokinek a kísérletes és emberi tumorok mikrokörnyezetében mindig felfedezhetők. A számos gyulladásos citokin közül az utóbbi időben egyre több figyelem irányul az interleukin-6 (IL6)-ra. Az IL6 egy pleiotrop hatású citokin, melyet számos sejttípus termel $[3,4]$. Fontos szerepet játszik az immunszabályozásban és a vérképzésben. Az egyik legfontosabb hatása, hogy részt vesz a daganatos sejtek osztódásában és differenciálódásában $[4,5]$. Ám mivel az IL6 elősegíti a B- és Tlymphocyták érését, illetve aktivációját, a tumorellenes immunválasz kialakulásában is szerepet játszik. Az IL6 fokozott termelódését írták le myeloma multiplexben [6], endometriumtumorokban [7], tüdőrákban [8], vesesejtes carcinomákban [9], méhnyakrákban [10,11] és emlőrákban [12]. Ezenkívül több tanulmány felvetette az IL6 szerepét a colorectalis tumorok kialakulásában és progressziójában is. Kimutatták, hogy emelkedett szérum-IL6-szint mérhetô vastag- és végbélrákokban [13, 14]. Kevés információ áll azonban rendelkezésre arról, hogy az IL6-expresszióhoz milyen klinikopatológiai jellemzók társulnak ezekben a tumorokban. Vizsgálatunk ezen kérdés megválaszolására irányult.

\section{Módszer}

Kutatásunkhoz az Uzsoki Utcai Kórházban 2004 és 2011 között operált 64, colorectalis tumoros beteg demográfiai, sebészeti és patológiai adatait gyújitöttük öszsze. Vizsgálatunkba szövettanilag igazolt adenocarcinomában szenvedő betegeket válogattunk be. A kizárás kritériumai a következők voltak: szinkron egyéb tumor, gyulladásos állapotok (tüdőgyulladás, sebgyulladás, tályog, epehólyag-gyulladás, branülgyulladás, endocarditis, húgyúti fertőzés, Crohn-betegség, colitis ulcerosa stb.) és szteroidterápia. A betegek stádiumait két, korai (I. és II. stádium) és előrehaladott (III. és IV. stádium) csoportra osztottuk. A szövettani metszeteket a Semmelweis Egyetem I. Sz. Patológiai és Kísérleti Rákkutató Intézetében $\mathrm{Abcam}^{\circledR}$ (Cambridge, Egyesült Királyság) IL6-antitesttel festettük meg, a sejtmagokat hematoxilinnel tettük láthatóvá. A szövettani metszeteket digitalizálás után a Pannoramic Viewer (3DHistech, Budapest) nevú programmal értékeltük ki. Első lépésben metszetenként öt területet jelöltünk ki, ügyelve arra, hogy a területeken a tumor- és a stromasejtek aránya megfeleljen az egész metszeten látott aránynak. Ezt követte az adenocarcinoma és a stroma sejtjeinek kijelölése. A tumorsejtek, illetve a stromasejtek festődési intenzitásának kiértékeléséhez a QuantCenter (3DHistech) programot alkalmaztuk. A program a színintenzitás alapján számszerüsítette a pozitivitást, és ezt erős, mérsékelt, gyenge és negatív csoportokba sorolta. Az első két csoportot "kifejezett”, a második kettőt pedig „nem kifejezett” IL6-expresszióként határoztuk meg.

\section{Statisztikai elemzés}

A számításokhoz deskriptív módszereket, kereszttáblát Fisher-féle egzakt próbával, egyutas varianciaanalízist (ANOVA), az adatok eloszlásától függően független mintás vagy páros t-próbát vagy Wilcoxon-féle előjeles rangtesztet, Spearman-féle korrelációt, a nemlineáris összefüggések vizsgálatához a prediktor változók másodés harmadfokú polinomjait is tartalmazó többváltozós regressziót, valamint keverthatás-modelleket alkalmaztunk. A prediktor változók az életkor, a nem, a tumorstádium, a differenciáltsági fok és a szövettani paraméterek voltak. A több kategóriát tartalmazó változók hatásszignifikanciáját (például tumorstádium) az egyes kategóriák szintjén és együttesen Wald-teszttel is vizsgáltuk.

A vizsgálatokat az ETT TUKEB 5022-7/2013/EKU (39.214) számú engedély birtokában végeztük. 


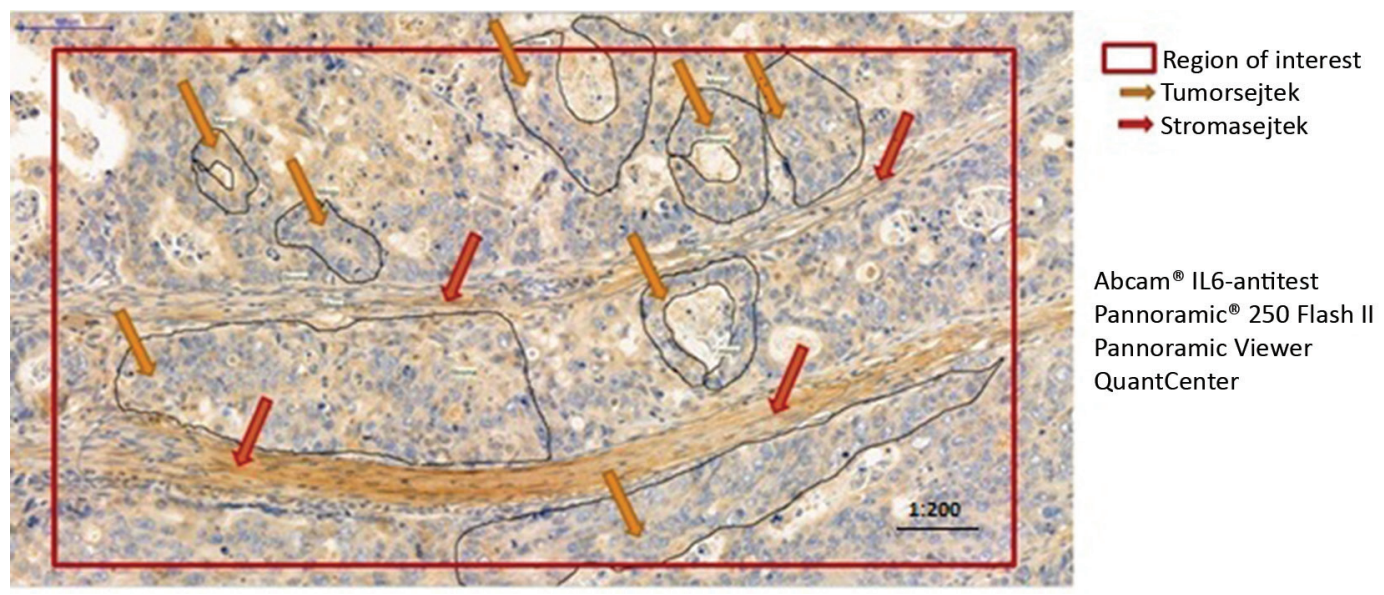

1. ábra $\quad$ Digitalizált IL6-festett metszeten a tumorsejtek láthatók kijelölve a ROI-n belül. A stromasejtek területeit piros nyilakkal jelöltük (színelemzéssel értékeltük ki a tumorsejtek és a stromasejtek IL6-pozitivitását)

IL6 = interleukin-6; ROI = (region of interest $)$ vizsgálati régió

1. táblázat |A betegek klinikopatológiai adatai

\begin{tabular}{llc}
\hline Kor & Átlag $( \pm$ SD) év & $64,2( \pm 11,3)$ \\
\hline Nem & Férfi & $40(62,5 \%)$ \\
& Nó & $24(37,5 \%)$ \\
\hline Stádium & I. (korai) & $15(23,4 \%)$ \\
& II. (korai) & $22(34,4 \%)$ \\
& III. (előrehaladott) & $19(29,7 \%)$ \\
& IV. (előrehaladott) & $8(12,5 \%)$ \\
\hline Differenciáltság (grade) $)$ & Jól differenciált & $10(15,6 \%)$ \\
& Közepesen differenciált & $41(64,1 \%)$ \\
& Rosszul differenciált & $13(20,3 \%)$ \\
\hline
\end{tabular}

$\mathrm{SD}$ = standard deviáció

\section{Eredmények}

A vizsgálatba 64 beteg került bevonásra (1. táblázat). A betegek átlagéletkora 64,2 év volt. A betegek közel kétharmada férfi volt. A korai stádiumú betegek aránya mérsékelten nagyobb volt a vizsgálati csoportban, mint az előrehaladott stádiumú betegeké ( $57,8 \%$ vs. 42,2\%). A tumorok jelentős része közepesen differenciált volt, a jól és rosszul differenciált daganatok közel hasonló arányban voltak kimutathatók.

A QuantCenter képanalízis-platform segítségével kiszámoltuk a tumor- és stromasejtek IL6-pozitív területeinek százalékos eloszlását. A gyulladásos sejteket nem jelöltük ki, egyrészt azért, mert nem minden metszeten találtunk gyulladásos beszürődést, másrészt ahol volt, ott nem észleltünk IL6-pozitivitást (1. ábra).

A betegek fó jellemzőit az egyes tumorstádiumok tekintetében a 2. táblázat mutatja. A tumorstádiummal a nem (Fisher-féle egzakt teszt, p =0,609) és az életkor (független mintás t-teszt, $\mathrm{p}=0,546$ ) nem mutatott szignifikáns összefüggést.

Különbségek mutatkoztak a tumor- és a stromasejtek IL6-kifejeződése között. A tumorsejtek $(44,8 \pm 22,9 \%)$ és a stromasejtek $(49,7 \pm 20,0 \%)$ IL6-expressziója között nem találtunk ugyan szignifikáns összefüggést (páros tteszt, $\mathrm{p}=0,057$ ), azonban a kifejezett (erős és mérsékelt színintenzitás) IL6-expressziót mutató sejtek aránya szignifikánsan magasabb volt a tumorsejtekben $(29,5 \pm$ $22,2 \%)$, mint a stromasejtekben $(22,1 \pm 13,2 \%)$ (Wilcoxon-próba, $\mathrm{p}=0,005$ ) (2. ábra).

Előrehaladott stádiumú betegekben a tumorsejtek IL6-expressziója szignifikánsan magasabbnak bizonyult

2. táblázat $\mid$ A betegek klinikopatológiai adatai a tumorstádium szerint

\begin{tabular}{llll}
\hline Tumorstádium & $\begin{array}{l}\text { Nem } \\
\text { (férfi/nó) }\end{array}$ & Átlagéletkor (év) & $\begin{array}{l}\text { Tumorsejt } \\
\text { IL6-pozitivitása (\%) }\end{array}$ \\
\hline Összes & $40 / 24$ & 64,2 & $\begin{array}{l}\text { Stromasejt } \\
\text { IL6-pozitivitása (\%) }\end{array}$ \\
\hline Korai (I-II.) & $15 / 22$ & 64,9 & 44,8 \\
\hline Elörehaladott (III-IV.) & $9 / 18$ & 63,1 & 40,7 \\
\hline Korai vs. előrehaladott & $\begin{array}{l}\text { Fisher-féle egzakt teszt } \\
\mathrm{p}=0,609\end{array}$ & $\begin{array}{l}\text { Független mintás t-teszt } \\
\mathrm{p}=0,546\end{array}$ & $\begin{array}{l}\text { Független mintás t-teszt } \\
\mathrm{p}=0,094\end{array}$ \\
\hline
\end{tabular}

IL6 = interleukin-6 


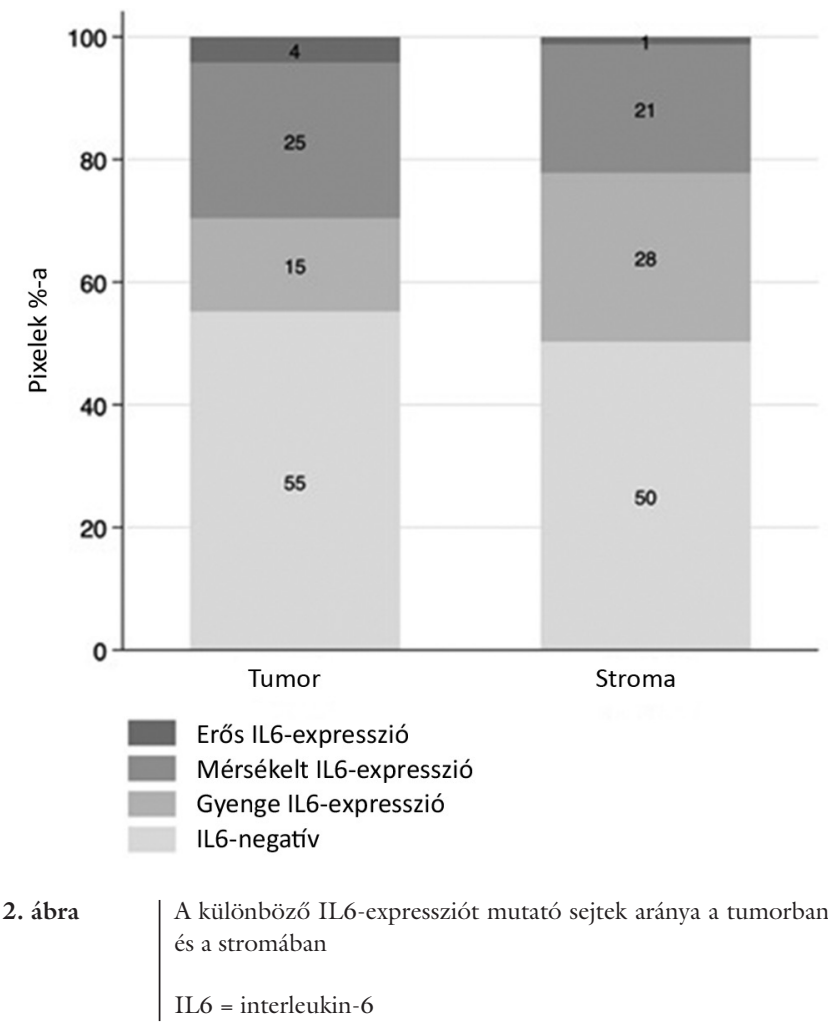

lineáris regresszióval. A stromasejtek IL6-expressziója nem mutatott összefüggést a tumorstádiummal (3. táblázat).

Több prediktor változó esetén nem találtunk szignifikáns összefüggést. Az esélyhányadosteszt egyik regreszsziós modellnél sem bizonyult szignifikánsnak $\left(\mathrm{M}_{1} \mathrm{p}=\right.$ 0,$\left.407 ; \mathrm{M}_{2} \mathrm{p}=0,272 ; \mathrm{M}_{3} \mathrm{p}=0,228 ; \mathrm{M}_{4} \mathrm{p}=0,126\right)$, ami arra utal, hogy összességében a klinikopatológiai para-

A) IL6-expresszió

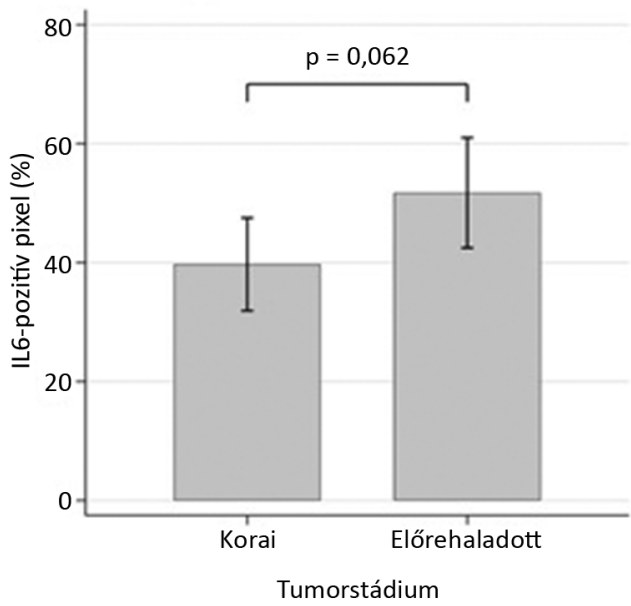

Hibasáv: 95\% megbízhatósági intervallum Oszlop: átlag (korrigált becslés)

3. ábra \begin{tabular}{|l} 
Az IL6-expresszió a tumorstádium függvényében \\
IL6 = interleukin-6
\end{tabular} \begin{tabular}{l|l} 
3. táblázat & $\begin{array}{l}\text { Az IL6-expressziót befolyásoló tényezók vizsgálata lineáris reg- } \\
\text { resszióval }\end{array}$
\end{tabular}

\begin{tabular}{llcc}
\hline & & \multicolumn{2}{c}{ Tumor } \\
\hline & $\begin{array}{l}\text { IL6-pozitív } \\
\text { pixel \% }\left(\mathrm{M}_{1}\right)\end{array}$ & $\begin{array}{l}\text { Kifejezett } \\
\text { IL6-pozitív } \\
\text { pixel } \%\left(\mathrm{M}_{2}\right)\end{array}$ \\
\hline Kor & Férfi & 1,61 & 0,06 \\
\hline Nem $^{\text {a }}$ & Elörehaladott & 12,02 & 2,15 \\
\hline Stádium $^{\text {b }}$ & $\begin{array}{l}\text { Közepesen } \\
\text { differenciált }\end{array}$ & 3,37 & $12,68^{*}$ \\
\hline Differenciáltság $^{\text {Rosszul }}$ & $-0,17$ & $-4,35$ \\
& differenciált & & \\
\hline
\end{tabular}

`bázis = női nem; 'bázis = korai stádium; ‘bázis = jól differenciált

IL6 = interleukin-6

méterek nem mutattak összefüggést az IL6-expresszióval. További regressziós modellekkel azt vizsgáltuk, hogy a tumorstádium befolyásolja-e az egyes klinikopatológiai paraméterek és az IL6-expresszió kapcsolatát, azonban nem sikerült ilyen összefüggést kimutatnunk. Az előrehaladott (III-IV.) tumorstádium esetén azonban a kifejezett festődést mutató pixelek aránya alapján nagyobb mértékủ IL6-expressziót találtunk a tumorszövetben (3. ábra).

\section{Megbeszélés}

Az IL6 fontos szerepet játszik a tumorok kialakulásában, a sejtvándorlásban, az invázióban, a proliferációban [15], az apoptózisban, a progresszióban [16, 17], az angioge-

\section{B) Kifejezett IL6-expresszió}

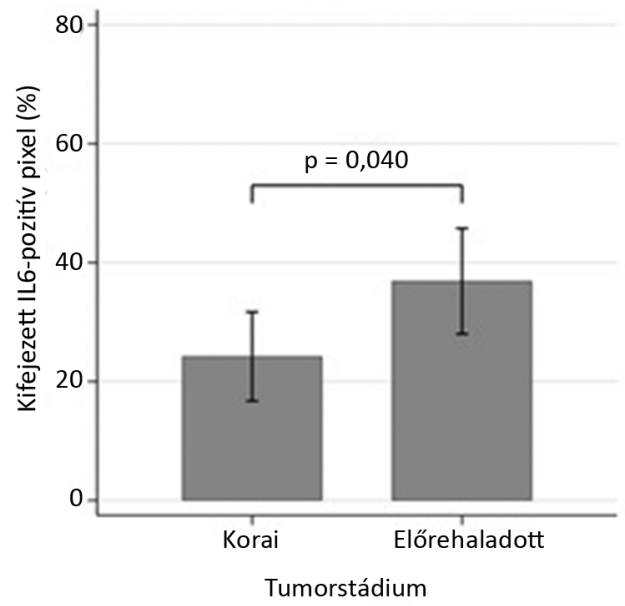


nezisben $[15,18]$ és a tumoros sejtek differenciálódásában [19]. Ahhoz, hogy a tumor korlátlanul osztódásnak induljon, ki kell kerülni a sejt szaporodását gátló tényezőket. Az IL6 által elindított jelátvitelnél a DNS-metiltranszferáz enzim (DNA methyltransferase, DNMT1) szintje megemelkedik a sejtben [20]; ennek során a p53 tumorszuppresszor gén promoter részén a CpG-sziget hipermetilálódik, ezzel a sejt önregulációja zavart szenved [21]. DNS-károsodás felléptekor a daganatsejtekben az IL6-szekréció fokozódik, ami a STAT3-aktiváción keresztül nemcsak a DNS-károsodás ellen hat, hanem a tumor növekedését potencírozza [22]. Ezt bizonyítja, hogy ha az IL6/STAT3 útvonal múködését gátoljuk - akár az IL6-on, gp130-on, akár a STAT3-on keresztül -, egyúttal lelassítjuk a DNS-károsodásnak kitett tumorsejt növekedését [23]. Úgy tünik, hogy az IL6 jelentôs hatással van a colorectalis tumorok sejtjeire is. Kimutatták, hogy az IL6 in vitro elósegíti a daganatos sejtek növekedését [15]. Ezenkívül az IL6 elősegíti a tumor progresszióját, mert bebizonyították, hogy dózisfüggő módon fokozza a daganatos sejtek kolóniaképződését [24]. Hatására növekszik a colorectalis carcinoma sejtjeinek invazivitása [25]. A tumorokban az IL6-ot leginkább maguk a tumorsejtek, a tumorasszociált macrophagok (TAM-ok), a CD4 T-sejtek, a fibroblastok és a myeloid eredetü szuppresszor sejtek (MDSC) expreszszálják [26, 27].

Legjobb tudásunk szerint eddig nem közöltek olyan releváns tanulmányt, melyben az IL6-expresszió szintjét antitesttel festett reszekált colorectalis tumoros betegekben biostatisztikai módszerekkel elemezték volna. Vizsgálatunk során a kifejezett IL6-expressziót mutató sejtek maguk a tumorsejtek voltak. Eredményeink alapján az IL6-expresszió mértékét nem befolyásolta szövettani differenciáltsági foka. Ez ellentmond Brozek és mtsai eredményeinek, akik kimutatták, hogy az IL6-szint normál humán nyálkahártyában alacsony mértékben, míg adenomákban, illetve jól differenciált (G1, G2) tumorokban csak kismértékben nő meg. Magas IL6-szintet kizárólag a rosszul differenciált elváltozásoknál (G3, G4) figyeltek meg [28]. A vizsgálat hátránya az alacsony esetszám, melynek alapján következtetéseiket levonták. Saját vizsgálatunkban emellett összefüggést találtunk az IL6expresszió és a daganatok stádiumai között. A rosszabb TNM-stádiumokhoz fokozottabb expresszió társult. Ezen eredményeink arra utalnak, hogy az IL6 összefüggést mutat a colorectalis tumorok inváziójával és áttétképződésével. Napjainkban egyre nagyobb figyelem irányul az anatómiai lokalizáció szerepére, ez azonban nem képezte vizsgálatunk tárgyát. A colon és a rectum mRNSés miRNS-expressziója között különbséget találtak [29]. A colonrákokban a BRAF, CTNNBl, PIK3Rl és SRC mutációi gyakoribbak, míg a rectumtumoroknál az APC, ERBB2, STK11 és TP53 mutációi fordulnak elő nagyobb arányban [30].

A szérum-IL6-szint emelkedésének mechanizmusa jelenleg nem ismert. Ennek egyik magyarázata a G/C po- limorfizmus lehet az IL6-gén promoter régiójának -174. pozíciójában. A -174C-allélról kisebb hatékonysággal íródik át fehérje, mint a -174G-allél esetében [31]. Belluco megállapította, hogy szignifikánsan magasabb szérum-IL6-szint mérhető azoknál a colorectalis tumoros betegeknél, akiknél az IL6-génben a -174G-polimorfizmus mutatható ki, mint akiknél a -174C [32]. Egérkísérletekben az anti-IL6-receptor-antitest-kezelés csökkentette a colitisasszociált vastagbélrák incidenciáját, így felmerül az IL6 mint terápiás célpont lehetôsége is [33].

\section{Következtetés}

Egyre növekvő számú bizonyítékok alapján az IL6 jelátvitele mind a sporadikus, mind a gyulladással összefüggő colorectalis tumorok progressziójában kritikus szerepet játszik. Hatása kiemelkedő a tumor inváziójában és metastasisképződésében. Különbségek mutatkoztak a tumorsejtek és a stromasejtek IL6-kifejeződése között. Az IL6 hasznos marker és potenciális terápiás célpont lehet az előrehaladott stádiumú vastag- és végbéltumoros betegek kezelésében.

Anyagi támogatás: A közlemény megírása, illetve a kapcsolódó kutatómunka anyagi támogatásban nem részesült.

Szerzôi munkamegosztás: J. V.: A szakirodalom áttekintése, a cikk szövegezése, statisztika. F. K.: Adatgyüjtés, mérések. Z. Zs.: Statisztika. R. L.: A szövettani mérések tervezése és beállítása. B. Zs.: A kutatás tervezése, a korrektúra elvégzése. A cikk végleges változatát valamennyi szerző elolvasta és jóváhagyta.

Érdekeltségek: A szerzőknek nincsenek érdekeltségeik.

\section{Irodalom}

[1] Kanavos P, Schurer W. The dynamics of colorectal cancer management in 17 countries. Eur J Health Econ. 2010; 10(Suppl 1): S115-S129.

[2] Flores BM, O'Connor A, Moss AC. Impact of mucosal inflammation on risk of colorectal neoplasia in patients with ulcerative colitis: a systematic review and meta-analysis. Gastrointest Endosc. 2017; 86: 1006-1011.e8.

[3] Jones SA, Jenkins BJ. Recent insights into targeting the IL-6 cytokine family in inflammatory diseases and cancer. Nat Rev Immunol. 2018; 18: 773-789.

[4] Rose-John S. Interleukin-6 family cytokines. Cold Spring Harb Perspect Biol. 2018; 10: a028415.

[5] Garbers C, Rose-John S. Dissecting interleukin-6 classic- and trans-signaling in inflammation and cancer. Methods Mol Biol. 2018; 1725: 127-140.

[6] McNee G, Eales KL, Wei W, et al. Citrullination of histone H3 drives IL-6 production by bone marrow mesenchymal stem cells in MGUS and multiple myeloma. Leukemia 2017; 31: 373-381.

[7] Cronin JG, Kanamarlapudi V, Thornton CA, et al. Signal transducer and activator of transcription-3 licenses Toll-like receptor 4-dependent interleukin (IL)-6 and IL-8 production via IL-6 
receptor-positive feedback in endometrial cells. Mucosal Immunol. 2016; 9: 1125-1136.

[8] Ogawa H, Koyanagi-Aoi M, Otani K, et al. Interleukin-6 blockade attenuates lung cancer tissue construction integrated by cancer stem cells. Sci Rep. 2017; 7: 12317.

[9] Wang Y, Fu D, Chen Y, et al. G3BPl promotes tumor progression and metastasis through IL-6/G3BP1/STAT3 signaling axis in renal cell carcinomas. Cell Death Dis. 2018; 9: 501.

[10] Song Z, Lin Y, Ye X, et al. Expression of IL- $1 \alpha$ and IL-6 is associated with progression and prognosis of human cervical cancer. Med Sci Monit. 2016; 22: 4475-4481.

[11] Wei LH, Kuo ML, Chen CA, et al. Interleukin-6 promotes cervical tumor growth by VEGF-dependent angiogenesis via a STAT3 pathway. Oncogene 2003; 22: 1517-1527.

[12] Gyamfi J, Lee YH, Eom M, et al. Interleukin-6/STAT3 signalling regulates adipocyte induced epithelial-mesenchymal transition in breast cancer cells. Sci Rep. 2018; 8: 8859. [Erratum: Sci Rep. 2020; 10: 13049.]

[13] Zhang X, Hu F, Li G, et al. Human colorectal cancer-derived mesenchymal stem cells promote colorectal cancer progression through IL-6/JAK2/STAT3 signaling. Cell Death Dis. 2018; 9: 25 .

[14] Galizia G, Orditura M, Romano C, et al. Prognostic significance of circulating IL-10 and IL-6 serum levels in colon cancer patients undergoing surgery. Clin Immunol. 2002; 102: 169-178.

[15] Johnson DE, O'Keefe RA, Grandis JR. Targeting the IL-6/ JAK/STAT3 signalling axis in cancer. Nat Rev Clin Oncol. 2018; 15: 234-248.

[16] Remeniuk B, King T, Sukhtankar D, et al. Disease modifying actions of interleukin- 6 blockade in a rat model of bone cancer pain. Pain 2018; 159: 684-698.

[17] Suchi K, Fujiwara H, Okamura S, et al. Overexpression of interleukin-6 suppresses cisplatin-induced cytotoxicity in esophageal squamous cell carcinoma cells. Anticancer Res. 2011; 31: 67-75.

[18] Keller ET, Wanagat J, Ershler WB. Molecular and cellular biology of interleukin-6 and its receptor. Front Biosci. 1996; 1: d340357.

[19] Brábek J, Jakubek M, Vellieux F, et al. Interleukin-6: molecule in the intersection of cancer, ageing and COVID-19. Int J Mol Sci. 2020; $21: 7937$.

[20] Liu CC, Lin JH, Hsu TW, et al. IL-6 enriched lung cancer stemlike cell population by inhibition of cell cycle regulators via DNMT1 upregulation. Int J Cancer 2015; 136: 547-559.

[21] Hodge DR, Peng B, Cherry JC, et al. Interleukin 6 supports the maintenance of p53 tumor suppressor gene promoter methylation. Cancer Res. 2005; 65: 4673-4682.
[22] Zhang C, Xin H, Zhang W, et al. CD5 binds to interleukin-6 and induces a feed-forward loop with the transcription factor STAT3 in B cells to promote cancer. Immunity 2016; 44: 913-923.

[23] Yun UJ, Park SE, Jo YS, et al. DNA damage induces the IL-6/ STAT3 signaling pathway, which has anti-senescence and growth-promoting functions in human tumors. Cancer Lett. 2012; 323: 155-160.

[24] Schneider MR, Hoeflich A, Fischer JR, et al. Interleukin-6 stimulates clonogenic growth of primary and metastatic human colon carcinoma cells. Cancer Lett. 2000; 151: 31-38.

[25] Hsu CP, Chung YC. Influence of interleukin-6 on the invasiveness of human colorectal carcinoma. Anticancer Res. 2006; 26: $4607-4614$.

[26] Chang Q, Bournazou E, Sansone P, et al. The IL-6/JAK/Stat3 feed-forward loop drives tumorigenesis and metastasis. Neoplasia 2013 ; 15: 848-862.

[27] Weber R, Groth C, Lasser S, et al. IL-6 as a major regulator of MDSC activity and possible target for cancer immunotherapy. Cell Immunol. 2021; 359: 104254.

[28] Brozek W, Bises G, Girsch T, et al. Differentiation-dependent expression and mitogenic action of interleukin- 6 in human colon carcinoma cells: relevance for tumour progression. Eur J Cancer 2005; 41: 2347-2354.

[29] Peng HW, Slattery M, Mann RS. Transcription factor choice in the Hippo signaling pathway: homothorax and yorkie regulation of the microRNA bantam in the progenitor domain of the Drosophila eye imaginal disc. Genes Dev. 2009; 23: 2307-2319.

[30] Hong TS, Clark JW, Haigis KM. Cancers of the colon and rectum: identical or fraternal twins? Cancer Discov. 2012; 2: 117121.

[31] Fishman D, Faulds G, Jeffery R, et al. The effect of novel polymorphisms in the interleukin-6 (IL-6) gene on IL-6 transcription and plasma IL-6 levels, and an association with systemiconset juvenile chronic arthritis. J Clin Invest. 1998; 102: 1369-1376.

[32] Belluco C, Olivieri F, Bonafè M, et al. $-174 \mathrm{G}>\mathrm{C}$ polymorphism of interleukin 6 gene promoter affects interleukin 6 serum level in patients with colorectal cancer. Clin Cancer Res. 2003; 9: 2173-2176.

[33] Yang H, Qi H, Ren J, et al. Involvement of NF- $\kappa$ B/IL-6 pathway in the processing of colorectal carcinogenesis in colitis mice. Int J Inflam. 2014; 2014: 130981.

(Baranyai Zsolt dr., Budapest, Üllői út 78., 1082 e-mail: baranyai.zsolt@med.semmelweis-univ.hu)

A cikk a Creative Commons Attribution 4.0 International License (https://creativecommons.org/licenses/by/4.0/) feltételei szerint publikált Open Access közlemény, melynek szellemében a cikk bármilyen médiumban szabadon felhasználható, megosztható és újraközölhető, feltéve, hogy az eredeti szerző és a közlés helye, illetve a CC License linkje és az esetlegesen végrehajtott módosítások feltüntetésre kerülnek. (SID_1) 